Article

\title{
Implications of Digital Inclusion: Digitalization in Terms of Time Use from a Gender Perspective
}

\author{
Lidia Arroyo \\ Internet Interdisciplinary Institute, Open University of Catalonia, 08860 Barcelona, Spain; E-Mail: larroyop@uoc.edu
}

Submitted: 31 October 2019 | Accepted: 7 January 2020 | Published: 14 May 2020

\begin{abstract}
The implications of digital technologies for the transformation of gender relations and identities have been discussed since the early days of the internet. Although gender studies have identified clear gender gaps in terms of digital inclusion as well as potentialities for the transformation of women's subjectivity, there is a lack of empirical evidence of the impact of digitalization in terms of time use from a gender perspective. Public policies have begun to address the digital gender gap, but the incorporation of a gender perspective in digital inclusion programmes which promotes women's emancipation by challenging the gender division of time through use of the internet has been not incorporated in the digital policies agenda. This article aims to provide empirical evidence of the mutual interrelation between the time allocation and digital inclusion from a gender perspective. It considers how gender inequalities in time use shape women's experience of digital inclusion and, at the same time, how digital inclusion promotes the reconfiguration of time in women's everyday lives. Qualitative analysis based on episodic interviews explored the representations and practices of internet use by women in their everyday lives. The sample was made up of 32 women who were digitally included through a lifelong learning programme in Spain and had experienced the effects of the Spanish economic crisis. The article argues that digital inclusion does not automatically lead to a more egalitarian allocation of time use for women, but rather places greater value on women's free time.
\end{abstract}

\section{Keywords}

digital gender gap; digital inclusion; gender division of labour; gender inequalities; internet use; time use

\section{Issue}

This article is part of the issue "Digital Inclusion Across the Globe: What Is Being Done to Tackle Digital Inequities?" edited by Bianca C. Reisdorf (University of North Carolina at Charlotte, USA) and Colin Rhinesmith (Simmons University, USA).

(C) 2020 by the author; licensee Cogitatio (Lisbon, Portugal). This article is licensed under a Creative Commons Attribution 4.0 International License (CC BY).

\section{Introduction}

Ensuring digital inclusion across the whole population has been a European Union policy priority during the first decade of the twenty-first century, in accordance with the goal of providing all citizens with the skills they need to meet the challenges of the digitalization of the economy and society (European Commission, 2010, 2016). European digital policies have been focused on providing digital skills to e-excluded social groups, which are also the groups with the fewest social opportunities (van Deursen \& van Dijk, 2014). Women, and particularly low-skilled women, have been one of the targets of these digital inclusion policies (Arroyo, 2018b; Arroyo \& Valenduc, 2016).
These policies assumed that digital inclusion would enable disadvantaged social groups to overcome other social inequalities and be better qualified to meet the demands of a digitalized labour market and society (European Commission, 2010, 2016). Yet there is little empirical evidence to explain how digital inclusion can effectively reduce social and gender inequalities and to what extent. Moreover, the issue of gender inequalities in time use is not considered in studies on the impact of the acquisition of digital skills acquisition programmes.

The reduction of the digital gap brought about by the greater availability of digital technologies across the whole population has opened up debate on whether there is a need to continue developing digital inclusion policies (Arroyo \& Valenduc, 2016; Sørensen, Faulkner, 
\& Rommes, 2011). At the present time, there is a need to provide empirical evidence on which gender and social inequalities are being reproduced and which are being transformed once the first digital gap has been overcome. Public policies have been geared towards addressing the digital gender gap, but the introduction of a gender perspective into digital inclusion programmesin terms of promoting women's emancipation by challenging the gender division of labour through internet usage-has not been incorporated into the digital policies agenda (Arroyo, 2018b).

This article aims to provide knowledge on how gender inequalities in time use shape women's experience of digital inclusion and, at the same time, how digital inclusion promotes the reconfiguration of time in women's everyday lives, focusing on women who were e-included through lifelong learning programmes in Spain and had experienced the economic crisis. This analysis provides empirical evidence that is useful for the formulation and design of public digital inclusion policies from a gender perspective.

\section{Theoretical Framework}

\subsection{Social Implications of Digital Inclusion from a Gender Perspective}

Early insights into the implications of digital technologies for the transformation of gender relations argued that the internet offered a great deal of potential to transform gender relations and identities (Haraway, 1991; Plant, 1998). In terms of time, as they suggest that the internet offers the possibility of adopting roles beyond gender stereotypes, digital inclusion could provide an opportunity to explore new time allocations that challenge the gender division of labour. Despite these theoretical proposals, there is a lack of empirical studies that have determined the potential impact of digital inclusion in terms of gender equality in time use.

Early empirical studies in the field analysed the consequences of being excluded in terms of social inequality by comparing the "haves" and "have-nots," but they assumed that opportunities for internet use are the same across the whole e-included population. This omission was noticed by the second wave of digital divide studies, which detected that access to technology alone does not lead directly to more social opportunities; they demonstrate that a person can be "info-excluded" despite having access to the internet. They went one step further by introducing the acquisition of e-skills and the different types of internet use in their analysis. These studies produced significant knowledge about the different types of use and showed how they are socially stratified (Valenduc, 2010; van Deursen \& van Dijk, 2014). From a gender perspective, the second wave of digital divide studies also highlighted how digital skills acquisition and uses of the internet are also gender stratified: Men have more advanced digital skills and use the internet more for leisure purposes than women (Castaño, 2008; Castaño, Martín, \& Martínez, 2011; Helsper, 2010).

Having identified the gaps in terms of skills and use, a third level of digital divide studies quantified the impact of these gaps in terms of the unequal distribution of benefits of internet use. Some take into account the variable gender as a socio-demographic characteristic of the sample but did not capture whether digital inclusion challenges gender inequalities such as the gender division of time and labour (Quan-Haase, Martin, \& Schreurs, 2016; Scheerder, van Deursen, \& van Dijk, 2017; van Deursen \& Helsper, 2015).

Studies that address the specific issue of internet time use are mainly concentrated on internet addiction, procrastination, or digital multitasking activities from a psychological perspective (Beavers, Bell, Choudhury, Guyot, \& Meier, 2015; Duff, Yoon, Wang, \& Anghelcev, 2014; Kim, Hong, Lee, \& Hyun, 2017; Müller, Fieseler, Meckel, \& Suphan, 2018; Vilhelmson, Thulin, \& Elldér, 2016). Their focus is on the impact of mental health issues but not on social factors and the implications of internet use for gender relations.

More comprehensively, studies adopting a mutual shaping approach point out how technologies and society are constantly influencing each other. They explore how digital technologies shape everyday life and, at the same time, how social inequalities and conditions affect the use and production of technologies. From a gender perspective, these studies have made essential contributions on how the use of digital technologies can be transformative or reproductive in terms of gender relations (Sørensen et al., 2011; Wajcman, 2004). In terms of gender division of time and labour, Wajcman (2004) highlights the importance of taking into account the unequal gender allocation of domestic and care work to understand the participation of women in the use and design of digital technologies.

Developing this user experience-focused approach, studies of everyday technology appropriation address the implications of digitalization, taking into consideration the meaning and relevance of the internet in the everyday lives of users (Hafkin \& Huyer, 2006; Silverston, 2005; Sørensen et al., 2011). This represents an important advance in that it identifies how users approach digital technologies, considering their own respective experiences. In this respect, the authors argue that people adapt their internet use according to their cultural background and everyday experiences (Simões, 2011; Tyler, 2002).

Despite the conceptual advances made, there remains a lack of empirical research on the mutual shaping of digital inclusion and gender inequalities in terms of time in women's everyday lives. The scant research in this area highlights that gender division of time and labour shapes women's internet experience (Casula, 2011; Simões, 2011).

This study is framed in the everyday technology appropriation approach from a gender perspective, consid- 
ering how gender inequalities in time use shape women's experience of digital inclusion and, at the same time, how digital inclusion promotes the reconfiguration of time in women's everyday lives. In order to incorporate more enriched analytical dimensions to address the issue of gender inequalities in time use of the internet, it is necessary to consider the contributions of studies of time from a gender perspective.

\subsection{Studies of Time from a Gender Perspective}

Studies of time from a gender perspective emerged from the reconceptualization of the "work" approach (Borderías, Carrasco, \& Alemany, 1994; Cordoni, 1993; Durán, 2006). This approach reformulated the concept of "work" to include paid employment as well as unpaid care work, introducing time spent on care work into their analysis at the same level as time spent on paid work (Borderías et al., 1994). These studies highlighted the importance and persistence of the gender division of labour, according to which paid, visible work in the labour market has been predominantly masculine, while care work, unpaid and invisible but essential in all societies, has tended to be carried out by women. In terms of time, it involves a gender division of time in which women dedicate more time to unpaid care and domestic labour, while men spend more time working in the labour market.

These studies showed how working hours in the labour market constrict and shape the temporal organization of everyday life, in symbolic as well as material terms (Cordoni, 1993; Moreno, 2007; Torns, Borràs, \& Moreno, 2006). This perspective also questions the social pact according to which time is organized in everyday life, such as the agreement on the division of the day into three fractions of eight hours (eight hours to work in the labour market, eight hours to rest and eight hours for leisure). Cordoni (1993) showed that the fraction designated as leisure time for men was time for care work in the case of women. This issue could have implications in terms of the amount of time available for internet use, and the type of digital use, according to gender.

Another consideration of this approach to analysing gender inequalities in time use is the importance of the synchronic perspective of time, which is particularly necessary due to the multiple roles constantly being simultaneously performed by women (i.e., mother/worker/daughter), and which require their simultaneous presence in terms of work (Prieto, 2015; Torns, 2008). To capture the different elements of the synchronic perspective of time and identify the interrelation between the institutional regulation of time, gender norms and the agency of women, these studies considered everyday life the proper context in which to capture these dynamics (Miguélez \& Torns, 1998; Prieto, 2015). In accordance with the everyday technology appropriation approach, examination of the dynamics of internet usage in a daily life context will be fruitful in capturing both the dynamics of the allocation of time and the significance and practice of women's use of digital technologies.

With regard to time allocation in the case of women, the most recent findings of these studies identify an important individualization process in women that affects the time structure of their lives. They show that the domestic norm-according to which women perceive their identity as primarily caregivers dedicating the most important times of their lives to care and domestic work-is diminishing (Callejo \& Prieto, 2015; Torns, Carrasquer, \& Grau, 2015). In contrast, women are now more oriented towards their professional development and spend more time in the labour market. However, this greater participation in the labour market has not been accompanied by a reallocation of care work, thus women suffer the consequences of the "double presence" that consists of assuming both paid work in the labour market and unpaid care work in the home (Carrasquer, 2009; Torns, 2008). The most recent studies also point to women's increasing demands for time for themselves (Torns et al., 2015). Examination of internet practices will provide the proper space in which to identify the role of digital inclusion in the process of women claiming and managing time for themselves.

This desire on the part of women to have more time for themselves has been affected by the economic crisis (Prieto, 2015). Long and irregular working hours, and reduced family purchasing power-which has led to the growth of care and domestic work-have increased "time poverty," particularly for low-skilled workers and women (García, 2017). It is pertinent to explore time issues in relation to digital inclusion at this moment of the crisis to capture whether internet use has played a role in facing the consequences of the crisis.

Considering the insights drawn from studies of time use from a gender perspective, our analysis of views and the significance of the impact of digital inclusion in time use among women in their everyday lives will provide the proper field in which to capture the dynamics of women's decisions on their use of time. It will also capture the role of digital inclusion in the reconfiguration of time use in women's everyday lives and changes in allocation of time (and work) among family members that challenge the gender division of time and labour.

\section{Methodology}

From a qualitative approach, we analysed the interrelations of time allocation according to use of the internet among women. The results are based on episodic interviews with 32 adult women who had participated in a lifelong learning programme of digital inclusion over the last 10 years in Spain.

The goal of these lifelong learning digital inclusion programmes was to provide basic digital skills to boost social opportunities for e-excluded citizens and disadvantaged social groups. This article does not aim to provide 
an evaluation of these programmes; however, the results of our analysis will provide recommendations for the design of digital inclusion public policies which address the issue of gender equality in time use.

The selection of the sample was performed by means of an on-line request to participate in the study; this was disseminated with the help of organizations who have implemented digital inclusion programmes in Spain over the last 10 years. The selected women were adult, working-age women (26-61 years old) who started to use the internet in the last 10 years. The women in the sample have experienced life without being connected to the internet and will therefore be able to identify changes produced in their everyday lives as a result of their digital inclusion.

As shown in Table 1, the participants came from different socio-educational backgrounds and age groups, but there was a higher representation of women over the age of 45 with a medium or low level of education. The participants' ages ranged from 26 to 61 years old, but nearly three quarters of them were 45 years old (12) or older (11). Educational attainment was equally distributed among women with a primary level of education or below (12) and women with a secondary education (12). Only eight of the participants had a higher level of educational attainment.

The characteristics of the sample are particularly relevant because the participants were mainly from disadvantaged social groups with respect to the digital sphere and the labour market. Women from older generations and with a low level of education experience the widest digital gaps (Arroyo \& Valenduc, 2016; van Deursen \& van Dijk, 2014) as well as the most precarious conditions in the labour market, which has deteriorated due to the economic crisis (Ficapal, Díaz, Sáinz, \& Torrens, 2018; Torns \& Recio, 2012).

The fieldwork was conducted between February and September 2014 during the period of economic crisis in Spain (García, 2017) and included 17 unemployed women and 15 employed women. This analysis is particularly relevant in the context of the impact of an economic crisis in which there has been a reallocation of time use in the everyday lives of an important part of the population, particularly in countries with higher levels of unemployment such as Spain (Prieto, 2015).

The episodic interviews (Flick, 2000) were structured into three parts. In the first part, interviewees were asked about their "digital biography" in order to discover their internet use trajectory and explore how they used the internet in their everyday lives. The second part consisted of narrower questions focused on the time available to interviewees to connect to the internet. In the third part, we explored the women's views with regard to the reallocation of time use in their everyday lives as related to their digital inclusion. Finally, the interview concluded with a question that asked what internet use recommendations the women would give to a hypothetical, e-excluded friend.

The interviews were coded using ATLAS.ti qualitative data analysis software, adapting the conceptual considerations from the everyday technology appropriation approach from a gender perspective, and the analytical dimensions of the studies of time use from a gender perspective, to the empirical material. To accomplish this, codification was structured into three main codes: time for connecting; time of connecting; and reconfigurations of time in their everyday lives.

\section{Results}

\subsection{Time for Connecting}

The "double presence" of women in both the labour market and unpaid care work is a key element that the interviewed women viewed as crucial in terms of time to connect to the internet and develop their digital skills. They stressed that the time available to them to connect to the internet depended on their labour situation and their domestic and family responsibilities, mentioning the scarcity of time available to use on the internet.

\subsubsection{Impacts of Time in Labour Market}

The employed women saw the time they dedicated to paid work as a limitation in terms of time to connect to the internet. They pointed out that their long working hours and level of tiredness when they arrived home did not allow them to spend time on the internet and put into practice the digital skills they had learned on their lifelong learning digital inclusion programme:

You don't have the same amount of time....You get home at half past ten exhausted, you get home exhausted. By the time you've had a shower, made din-

Table 1. Distribution of the sample by age group and educational attainment.

\begin{tabular}{lcccc}
\hline & $\begin{array}{c}\text { Primary education } \\
\text { or below }\end{array}$ & $\begin{array}{c}\text { Secondary } \\
\text { education }\end{array}$ & $\begin{array}{c}\text { Higher } \\
\text { education }\end{array}$ & $\begin{array}{c}\text { Total by } \\
\text { age group }\end{array}$ \\
\hline $25-29$ & 1 & 0 & 0 & 1 \\
$30-44$ & 3 & 4 & 1 & 8 \\
$45-54$ & 4 & 2 & 6 & 12 \\
$55+$ & 4 & 6 & 1 & 11 \\
Total according to educational attainment & 12 & 12 & 32 \\
\hline
\end{tabular}


ner and cleared up, it's twelve-thirty at night, you think at twelve-thirty I'm going to get on the computer to look something up? What I want is to get into bed.... (46-year-old employed woman)

Along the same line, women also mention that they have invested more time on the internet when they have had periods without employment. In some cases, periods of unemployment or maternity leave have been crucial to developing their digital skills, enabling them to participate in lifelong learning digital inclusion programmes:

I started...as a result of getting pregnant with my little girl, my work plan changed and I found myself at home and I said, "This is my opportunity." I started doing courses in office information technology, internet.... (48-year-old unemployed woman)

This scarcity of time available for connecting to the internet linked to dedication to work is related to the central role of working hours in the time allocation of women's everyday lives (Cordoni, 1993; Torns, 2008), together with longer and more irregular working hours as a consequence of the economic crisis (García, 2017).

\subsubsection{Impacts of Time for Care Work}

Care work linked to family responsibilities is the other key element that women identify as a determinant of the time available to them for connecting to the internet and developing their digital skills. All the women indicated that the time they spent on the internet was determined by their family responsibilities. In concordance with previous studies on the impact of familiar responsibilities on internet use (Casula, 2011; Simões, 2011), our interviewees highlighted the scant amount of time they had to devote to the internet, due to "double presence" and their care responsibilities. Most employed women with family responsibilities say they do not have time.

Employed women usually spend time on the internet in the evenings when they have finished all the domestic and care tasks. Women with young children indicate that they are only available to connect to the internet after completing their care tasks, but this is also the case for women with older children and women who live with other care receivers, such as one woman who looked after her father:

Yes, I have Facebook, and the truth is I do not use it at all. Because all of this takes time, and I do not have time....My daughter takes up all my time. What, you say, 14 years old and still taking up all your time? Yes, because you have to take her places, then you have to pick her up. (50-year-old employed woman)

Unemployed mothers used the times when their children were at school, watching TV, or playing with the tablet to connect to the internet. Only one woman indi- cated that she had no problems in terms of time to connect to the internet:

I still have time for everything. I used to work from morning to night and we still had time to do things, so now even more so.... I don't have young kids, that's also true, and it's different when you have grandchildren, you say....Because now grandparents are making a lot of sacrifices to care for their grandchildren. (57-year-old unemployed woman)

With the exception of this one woman, a widow with no family responsibilities, it is important to notice that not only women with young children mention the lack of time to connect to the internet due to family responsibilities. Women with older children or other care receivers are also affected by lack of time due to their care responsibilities.

\subsection{Uses of the Internet and Reconfigurations of Time in Everyday Life}

\subsubsection{Time of Work Related to Labour Market}

The interviewees-women that acquired their digital skills through lifelong learning digital inclusion programmes-did not use the internet in their everyday working lives, with the exception of those with postsecondary education or higher education who are clerical workers, business owners, or teachers.

The clerical workers only used the internet in their job to search for specific information, such as details of how to use new software or for making travel arrangements for their bosses. Of the two entrepreneurs who used the internet for work purposes, one-a newsstand owner-only used the internet for concrete management issues; but the other, the owner of a marquetry craft workshop, spent more time on the internet to promote their creations maintaining a blog and social networks. The teachers reported more intensive use of the internet searching for pedagogical resources and viewed the internet as essential for maintaining up-to-date teaching content and relationships with their colleagues.

Among the non-qualified workers, only one immigrant woman, who works as a care worker, used the internet to look for receipts to prepare meals for the care receivers she provides care for:

Because this July, I worked at a house here, a couple, taking care of a couple. I also prepared food. And sometimes she would say to me, "Tomorrow I want you to make me this meal." And I write it down on a piece of paper and when I get home I look it up on the internet and it helps me. And the next day when I go to the lady I say, "Ah, I know how to make lunch." And she says, "What?" And I say, "We do this, and this, and this." And she says, "Yes, ma'am!" Yes, it does help me, 
yes....That's what I say. The internet helps me a lot, it helps me a lot. (38-year-old unemployed woman)

While use of the internet for performing the main tasks of their jobs was reduced, as many of them were adversely affected by the economic crisis, job search was the main use in relation to the labour market. These women mainly used the internet to search for job offers and send their CVs. In the case of immigrant women, they also used the internet to look for the geolocation of a business when they have to go to a job interview (Arroyo, 2018a).

With regard to the reconfiguration of working time in relation to internet use, the women interviewed did not appreciate significant changes, with the exception of teachers, who indicated that they now had to invest more time in updating teaching materials to adapt their classes to the digitalization of the learning process. Regarding job search, only five women found a job using online job search tools, while the rest of the sample experienced no change in terms of reconfiguration of time in their lives due to internet use.

Although the generalized use of the Internet to find a job was mainly used by the unemployed interviewees, the women mostly defined the time they spent on the internet as time for themselves.

\subsubsection{Time for Themselves}

The women interviewed said they spend time on the internet when they had some time available for themselves: when they were alone, bored, had some free time, or needed to look for specific information:

I never find the right moment, when I'm at home I've got no time for messing around.... But since I'm alone in the morning, because they're out delivering newspapers for two hours in the morning....And sometimes that is the right moment, because they have had to go out. (59-year-old employed woman)

The internet is an ally of the scarce amount of time the women had available for themselves. Women who previously spent time reading or writing considered that the time they spent connecting to the internet had superseded the time they used to spend connecting with themselves, commenting that the internet offered contents that required less concentration and dedication than reading a book or writing. These easily consumed contents are considered most suitable when they are tired or have little time to dedicate to themselves. The internet is used as a tool to manage the "time poverty" which has been aggravated by the economic crisis (García, 2017):

Before? For example, when I'd finished clearing everything up, I would sit down, and if I had a story to tell, I would write. I used to read something but [laughs]. I write less because, of course, now the internet now gives me bite-sized chunks of information, you start watching YouTube videos. (35-year-old unemployed woman)

Exploring the significance of internet use allows us to capture the nuanced meanings of "time for themselves" as defined by the women interviewed. It is noteworthy that what they define as "time for themselves" is not the same as leisure time. Some of them use the internet for entertaining purposes, such as chatting with friends, or sharing jokes or beautiful images with their friends, but most of them stress that they mainly use the internet for useful purposes such as searching for specific information related to particular news stories, the geolocation of places, health issues, or information to organize holidays or other family entertainment arrangements.

The women interviewed stressed the distance between themselves and other people with plenty of free time to use the internet. They indicate that they are aware of the risk of addiction and explain that there are people who waste a lot of time playing games or sharing junk and nonsense content. Women who recognized having experienced the sensation of being absorbed when browsing the internet immediately stressed that they had self-control and that their internet activity did not interfere with their fulfilling their responsibilities. This was particularly emphasized among unemployed women:

We get so caught up in things. Me not so much, but I get on the internet and if I start browsing crafts, the world goes away and that's where I stay. I start to search, and one link leads me to another and okay, click on here and I go here, I go there, I go all over the place, I get totally absorbed in that world and the hours just go by....Sure, it's happened to me, too, but I control it. (40-year-old unemployed woman)

This distance the unemployed women place between their internet behaviour and that of people who waste their time on the internet is related to the findings of previous research, which indicate a very strong link between procrastination on the internet and feelings of guilt (Müller et al., 2018), together with the pressure for unemployed people to not allow themselves leisure time (Prieto, 2015). Moreover, it is related to the responsibilities of women as caregivers and the perceived importance of using their time in useful activities (García, 2017; Torns, 2008).

\subsubsection{Time for and Redistribution of Care Work}

In terms of time spent on caregiving and domestic work, all the women used the internet in their care tasks: to look for recipes, information and resources for children; communicate with family members and friends linked to take care of them; organize family activities; and manage household affairs.

However, two of the women indicated that they reduced the time they spent in conversation with their fam- 
ily members and friends linked to taking care of them. With regard to time for household management, two women also mentioned the time saved as a result of the digitalization of banking services. Both of them appreciated that their use of online bank accounts saved them scarce and precious time by not having to go in person to the bank:

It is a tool that saves you a lot of time because, if you are working, the time you have to be there in the bank, sometimes for nothing, because it is for nothing, sometimes you're there for three hours waiting for your turn. And now on the internet you do it at home in five minutes. You save yourself from having to say, "Now I have to go to the bank and squander two hours of my time." (45-year-old employed woman)

Regarding the reallocation of work, the women interviewed indicated that they had experienced no change in terms of the reallocation of time for care responsibilities and domestic labour within their families as a result of their digital inclusion. They continued to bear the primary responsibility for caregiving and domestic work in their families (Torns, 2008).

Even though the gender division of labour remained the same, one married woman had started to defend her own time on the internet in a manner that involves negotiation as to who does the domestic work:

Far from it, I have to say....And sometimes I think, "It's time you organized yourself, isn't it?" And then I say, "Every day I will have my two hours on the computer, come what may, and if the house is dirty, whoever wants it clean can clean it, but I will have my two hours and I will browse the web, do my blog or do something else or look something up." (59-year-old employed woman)

It is noteworthy that digital inclusion does not involve a material reallocation of time in women's lives and among family members. However, it can bring about change in terms of women negotiating time for themselves to connect to the internet, together with self-imposed control of time spent.

\section{Conclusion and Policy Implications}

Our results show that the time available to women for connecting to the internet and the types of use they make of the internet are shaped by the gender allocation of time. The "double presence" of women in both the labour market and unpaid care work is a key element that the women interviewed saw as crucial in terms of time to connect to the internet and develop their digital skills. It is also important to note that it is not only women with young children who point to a lack of time to connect to the internet due to family responsibilities. Women with older children and women who are responsible for other care receivers, such as older parents, are also affected by lack of time due to their care responsibilities.

Women see their dedication to paid work as a limitation in terms of time to connect to the internet. Many of them use periods of unemployment or maternity leave to invest in the acquisition of digital skills to improve their employment position. Employed women reported that they now had less time, and that they had replaced reading or writing time for themselves with connecting to the internet. Rapid access to less demanding content is seen as a strategy for dealing with the worsened conditions of time linked to the impact of the economic crisis (García, 2017).

The women interviewed, particularly the nonqualified workers, do not associate their internet use with their work in the labour market. Few of them use the internet in their daily working lives. This dissociation between internet use and the labour market in women who acquire digital skills through lifelong learning programmes must be take into account in the reformulation of digital inclusion policies. On the one hand, it is important that digital inclusion programmes include skills and resources that women can apply to their jobs in order to reduce the unequal distribution of the benefits of participating in lifelong learning programmes (Luchinskaya \& Dickinson, 2019). On the other, it is important that labour market policies support workplace digitalization and consider the contribution made by all workers, including those in low-skilled positions (Arroyo, 2018b).

Time on the Internet was mainly viewed as time for themselves. But analysis of the nuances of meaning, it showed that, for these women, "time for themselves" on the internet is not the same as "leisure time." Although they associated time on the internet as time for themselves, they stressed that they did not waste time on the internet, rather utilizing it for useful activities, particularly in the case of the unemployed women. This is related to the gender social norm of women as primary caregivers and also to the pressure on unemployed people to not allow themselves leisure time (Müller et al., 2018; Prieto, 2015).

It is noteworthy that digital inclusion does not lead to a material reallocation of time in women's lives and among family members and the gender division of labour remained the same. All the women connect to the internet after they have completed their care and domestic responsibilities and none of them identified any changes in time spent on care tasks, with the exception of one woman who was a widow without any family responsibilities. However, digital inclusion has brought about some changes in terms of women negotiating time for themselves to connect to the internet that suggests a demand for meaningful time of their own, as identified by previous studies (Torns et al., 2015).

In terms of policy recommendations, it is important to note that digital inclusion policies must be accompanied by other social policies. On the one hand, time allocation policies are needed to reorganize the social regula- 
tion of times in which working hours allow time for caregiving tasks as well as leisure time and meaningful time for oneself (Cordoni, 1993; Torns et al., 2015). On the other, there is an important need for co-responsibility policies promoting the sharing of care and domestic responsibilities between women and men (Cordoni, 1993; Torns, 2008).

\section{Acknowledgments}

The author expresses her gratitude to all the women who participated in this study, sharing their precious time and experience. She would also like to thank the coordinators of digital inclusion public policies and programmes who generously opened the door of their organisations and projects. She is also grateful to Dr Jörg Müller and Dr Teresa Torns for their valuable contributions during the knowledge-building process as well as the anonymous reviewers and editors for their constructive comments on previous versions of this manuscript.

\section{Conflict of Interests}

The author declares no conflict of interests.

\section{References}

Arroyo, L. (2018a). Digital inclusion for better job opportunities? The case of women e-included through lifelong learning programmes. In P. Bilić, J. Primorac, \& B. Valtýsson (Eds.), Technologies of labour and the politics of contradiction (pp. 141-158). Cham: Palgrave Macmillan.

Arroyo, L. (2018b). Las competencias digitales para el crecimiento económico en igualdad de oportunidades en España y la Unión Europea [Digital skills for economic development from an equal opportunities approach in Spain and European Union]. Madrid: Fundación Alternativas. Retrieved from https://www.fundacionalternativas.org/estudiosde-progreso/documentos/documentos-de-trabajo/ las-competencias-digitales-para-el-crecimientoeconomico-en-igualdad-de-oportunidades-enespana-y-la-union-europea

Arroyo, L., \& Valenduc, G. (2016). Digital skills and labour opportunities for low-skilled woman (Dynamics of Virtual Work Working Paper No. 6). Hertfordshire: University of Hertfordshire. Retrieved from http:// dynamicsofvirtualwork.com/wp-content/uploads/ 2015/08/COST-Action-IS1202-Working-Paper-6.pdf

Beavers, L., Bell, R., Choudhury, D., Guyot, W., \& Meier, R. (2015). Online time and gender perceptions of internet addiction. Journal of Higher Education Theory and Practice, 15(3), 84-98.

Borderías, C., Carrasco, C., \& Alemany, C. (Eds.). (1994). Las mujeres y el trabajo: Rupturas conceptuales [Women and work: Conceptual ruptures]. Barcelona: Icaria.
Callejo, J., \& Prieto, C. (2015). Distribución y organización de los tiempos de trabajo, cuidados y ocio con una perspectiva de género [Distribution and organization of labour, care and leisure times from a gender perspective]. In C. Prieto (Ed.), Trabajo, cuidados, tiempo libre y relaciones de género en la sociedad española [Work, care, free time and gender relations in the Spanish society] (pp. 53-86). Madrid: Ediciones Cinca.

Carrasquer, P. (2009). La doble presencia: El trabajo y el empleo femenino en las sociedades contemporáneas [The twofold presence, identifies the work and employment of most women in Spain and in contemporary societies] (Unpublished Doctoral dissertation). Department of Sociology, Autonomous University of Barcelona, Cerdanyola del Vallès, Spain.

Castaño, C. (2008). La segunda brecha digital [The second digital divide]. Madrid: Cátedra.

Castaño, C., Martín, J., \& Martínez, J. L. (2011). La brecha digital de género en España y Europa: Medición con indicadores compuestos [The digital divide from a gender perspective in Spain and Europe: Measuring with composite indicators]. Reis: Revista Española de Investigaciones Sociológicas, 136(1), 127-140.

Casula, C. (2011). L'enracinement social des inégalités numériques: La difficile intégration des femmes italiennes à la société de l'information [Social roots of digital inequalities: The difficult integration of Italian women in the information society]. Tic\&société, 5(1). Retrieved from https://journals.openedition. org/ticetsociete/987

Cordoni, E. (1993). Las mujeres cambian los tiempos [Women changing the times]. Cuadernos de Relaciones Laborales, 2, 221-237.

Duff, B. R.-L., Yoon, G., Wang, Z., \& Anghelcev, G. (2014). Doing it all: An exploratory study of predictors of media multitasking. Journal of Interactive Advertising, 14(1), 11-23.

Durán, M. A. (2006). El valor del tiempo [The value of time]. Madrid: Espasa-Calpe.

European Commission. (2010). Europe 2020: A strategy for smart, sustainable and inclusive growth (COM [2010]). Brussels: European Commission. Retrieved from http://eurlex.europa.eu/LexUriServ/ LexUriServ.do?uri=COM:2010:2020:FIN:EN:PDF

European Commission. (2016). A new skills agenda for Europe: Working together to strengthen human capital, employability and competitiveness (COM [2016]). Brussels: European Commission. Retrieved from https://ec.europa.eu/transparency/regdoc/ rep/1/2016/EN/1-2016-381-EN-F1-1.PDF

Ficapal, P., Díaz, A., Sáinz, M., \& Torrens, J. (2018). Gender inequalities in job quality during the recession. Employee Relations, 40(1), 2-22.

Flick, U. (2000). Episodic interviewing. In M. W. Bauer \& G. Gaskell (Eds.), Qualitative researching with text, image and sound: A practical handbook (pp. 75-93). London: Sage Publications. 
García, C. (2017). El impacto de la crisis económica en la pobreza de tiempo y la desigualdad de género [The impact of the economic crisis on time poverty and gender inequalities]. Arbor, 193(784), a382. https:// doi.org/10.3989/arbor.2017.784n2005

Hafkin, N. J., \& Huyer, S. (2006). Cinderella or Cyberella? Empowering women in the knowledge society. Bloomfield, CT: Kumarian Press.

Haraway, D. J. (1991). Simians, cyborgs and women: The reinvention of nature. New York, NY: Routledge.

Helsper, E. J. (2010). Gendered internet use across generations and life stages. Communication Research, 37(3), 352-374.

Kim, J., Hong, H., Lee, J., \& Hyun, M.-H. (2017). Effects of time perspective and self-control on procrastination and internet addiction. Journal of Behavioral Addictions, 6(2), 229-236.

Luchinskaya, D., \& Dickinson, P. (2019). 'Virtuous' and 'vicious' circles? Adults' participation in different types of training in the UK and its association with wages. Social Inclusion, 7(3), 177-201.

Miguélez, F., \& Torns, T. (1998). Introducción al análisis del trabajo y de la vida cotidiana [Introduction for the analysis of work and daily life]. Papers: Revista de Sociologia, 55, 9-25.

Moreno, S. (2007). Temps, treball i benestar: Una aproximació des de la vida quotidiana [Time, work and wellbeing: An everyday life approach] (Unpublished Doctoral dissertation). Department of Sociology, Autonomous University of Barcelona, Cerdanyola del Vallès, Spain.

Müller, S., Fieseler, C., Meckel, M., \& Suphan, A. (2018). Time well wasted? Online procrastination during times of unemployment. Social Science Computer Review, 36(3), 263-276.

Plant, S. (1998). Zeros and ones: Digital women and the new technoculture. London: Fourth Estate.

Prieto, C. (Ed.). (2015). Trabajo, cuidados, tiempo libre y relaciones de género en la sociedad española [Work, care, free time and gender relations in the Spanish society]. Madrid: Ediciones Cinca.

Quan-Haase, A., Martin, K., \& Schreurs, K. (2016). Interviews with digital seniors: ICT use in the context of everyday life. Information, Communication \& Society, 19(5), 691-707.

Scheerder, A., van Deursen, A., \& van Dijk, J. (2017). Determinants of internet skills, uses and outcomes: A systematic review of the second- and third-level digital divide. Telematics and Informatics, 34(8), 1607-1624.

Silverston, R. (2005). Media, technology and everyday life in Europe: From information to communication. New York, NY: Ashgate.

Simões, M. J. (2011). Género e tecnologias da informação e da comunicação no espaço doméstico: Não chega ter, é preciso saber, querer e poder usar [Technolo- gies of information and communication in the domestic space: It is not enough to have, you need to know, to want and be able to use]. Configurações, 2011(8), 155-162.

Sørensen, K. H., Faulkner, W., \& Rommes, E. (2011). Technologies of inclusion: Gender in the information society. Trondheim: Tapir Academic Press.

Torns, T. (2008). Tiempos de trabajo, tiempos de vida [Times of work, times of life]. Gaceta Sindical: Reflexión y Debate, 10, 253-274.

Torns, T., \& Recio, C. (2012). Desigualdades de género en el mercado de trabajo: Entre la continuidad y la transformación [Gender inequalities in labour market: Between the continuity and the transformation]. Revista de Economía Crítica, 14, 178-202.

Torns, T., Borràs, V., \& Moreno, S. (2006). La vida quotidiana: Exploració d'un marc conceptual i d'una proposta d'indicadors [Everyday life: Exploration of a conceptual framework and a proposal of indicators] (Working Paper QUIT No. 10). Cerdanyola del Vallès: Department of Sociology, Autonomous University of Barcelona.

Torns, T., Carrasquer, C., \& Grau, A. (2015). El trabajo de los cuidados entre el trabajo profesional y el tiempo de libre disposición personal: Perspectiva de género [The work of care between the professional labour and the free disposal time: Gender perspective]. In C. Prieto (Ed.), Trabajo, cuidados, tiempo libre y relaciones de género en la sociedad española [Work, care, free time and gender relations in the Spanish society] (pp. 109-136). Madrid: Ediciones Cinca.

Tyler, T. R. (2002). Is the internet changing social life? It seems the more things change, the more they stay the same. The Journal of Social Issues, 58(1), 195-205.

Valenduc, G. (2010). The second order digital divide: Synthesis of the research report. Namur: Fondation Travail-Université. Retrieved from http://www. ftu-namur.org/fichiers/FTU-Second_order_digital_ divide-Synthesis.pdf

van Deursen, A. J. A. M., \& Helsper, E. J. (2015). The third-level digital divide: Who benefits most from being online? In L. Robinson, J. Schulz, \& H. S. Dunn (Eds.), Communication and information technologies annual (pp. 29-52). Basingstoke: Emerald Group Publishing.

van Deursen, A. J. A. M., \& van Dijk, J. A. G. M. (2014). Digital skills: Unlocking the information society. New York, NY: Springer.

Vilhelmson, B., Thulin, E., \& Elldér, E. (2016). Where does time spent on the internet come from? Tracing the influence of information and communications technology use on daily activities. Information, Communication \& Society, 20(2), 250-263.

Wajcman, J. (2004). Technofeminism. Cambridge: Polity Press. 


\section{About the Author}

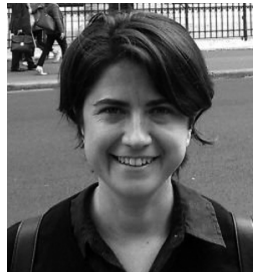

Lidia Arroyo is a Researcher in the Gender and ICT Research Group at the Internet Interdisciplinary Institute (IN3), Open University of Catalonia (UOC), as well as an Assistant Professor at the Universitat Autònoma de Barcelona (UAB). She holds an Advanced Studies Diploma (DEA) from the UAB's doctoral programme in Sociology. She is currently involved in European projects on gender and science (GenPORT, ACT, EFFORTI) and digital innovation (+Resilient). Her research interests include gender inequalities in digitalization, labour market inequalities and gender-related public policies. 